\title{
Maintenance of sperm production in bucks during a third year of short photoperiodic cycles
}

\author{
JA Delgadillo 1, B Lebœuf 2, P Chemineau $3^{\star}$ \\ ${ }^{1}$ Universidad Autónoma Agraria Antonio Narro, Carretera a Sta Fé y Periférico, Apdo Postal 940, \\ Torreón, Coahuila, México; \\ ${ }^{2}$ INRA, Station Expérimentale d'Insémination Artificielle, 86480 Rouillé; \\ 3 INRA, Neuroendocrinologie Sexuelle, Station de Physiologie de la Reproduction, \\ 37380 Nouzilly, France
}

(Received 26 March 1993; accepted 6 October 1993)

\begin{abstract}
Summary - We have previously shown that reproductive seasonality of bucks was prevented for 2 consecutive years by short photoperiodic cycles. To determine the effect of the length of treatment time on bucks subjected to the same photoperiod conditions, experiments were continued for a third consecutive year on 3 groups of 6 Alpine and Saanen bucks. The control group was kept under natural photoperiodic conditions, while the experimental groups were exposed alternately to 1 month of long days and 1 month of short days (group 2M) or to 2 months of long days and 2 months of short days (group, 4M). Prolactin profiles indicated that bucks from both experimental groups responded adequately to rapid photoperiod changes as their plasma prolactin levels were significantly higher in long days (mean $\pm \mathrm{SEM}$; $2 \mathrm{M}: 61.1 \pm 15.9 \mathrm{ng} / \mathrm{ml} ; 4 \mathrm{M}$ : $102.2 \pm 13.5 \mathrm{ng} / \mathrm{ml}$ ) than in short days $(2 \mathrm{M}$ : $35.3 \pm 8.2 \mathrm{ng} / \mathrm{ml} ; 4 \mathrm{M}: 46.1 \pm 9.0 \mathrm{ng} / \mathrm{ml}$ ). Testosterone secretion was also dependent on day length $(P<0.0001)$, since testosterone concentrations of experimental animals were higher during long days ( $2 \mathrm{M}: 7.0 \pm 0.7 \mathrm{ng} / \mathrm{ml} ; 4 \mathrm{M}: 10.2 \pm 1.1 \mathrm{ng} / \mathrm{ml}$ ) than during short days $(2 \mathrm{M}: 4.3 \pm 0.4 \mathrm{ng} / \mathrm{ml} ; 4 \mathrm{M}: 5.0$ $\pm 0.9 \mathrm{ng} / \mathrm{ml}$ ). Furthermore, controls displayed a high level of sexual behavior (always higher than $10 \%)$ and the proportion of bucks unable to ejaculate was significantly lower $(P<0.01)$ than the experimental animals (2M: $25.6 \% ; 4 \mathrm{M}: 28.1 \%$ ). In controls, the testis weights exhibited distinct seasonal variations, increasing from $120.0 \pm 0.1 \mathrm{~g}$ in May to $155.0 \pm 4.2 \mathrm{~g}$ in November, whereas in the experimental animals, the testis weights remained elevated $(2 \mathrm{M}$ : May $=160.0 \pm 7.3 \mathrm{~g}$, November $=$ $151.6 \pm 7.3 \mathrm{~g}$; $4 \mathrm{M}$ : May $=155.00 \pm 11.8 \mathrm{~g}$, November $=160.0 \pm 12.2 \mathrm{~g}$ ). Importantly, the mean total number of spermatozoa per ejaculate throughout the year was higher $(P<0.05)$ in experimental animals (2M: $\left.7.8 \pm 0.5 \times 10^{9} ; 4 \mathrm{M}: 7.8 \pm 0.310^{9}\right)$ than in the controls $\left(5.0 \pm 0.2 \times 10^{9}\right)$ and the mean daily sperm output, measured after exhaustion tests at the end of the photoperiodic treatments, was also higher $(P<0.05)$ in experimental animals $\left(2 \mathrm{M}\right.$ : $3.68 \pm 0.59 \times 10^{9} ; 4 \mathrm{M}$ : $\left.6.25 \pm 0.61 \times 10^{9}\right)$ than in controls $\left(2.96 \pm 0.36 \times 10^{9}\right)$. It was concluded that bucks exposed to rapid alternations between long and short days for a third year maintained a high sperm production and, thus, the seasonality of hypothalamo-pituitary-testis activity was abolished.
\end{abstract}

photoperiod / testosterone / prolactin / testis / goat

Résumé - Maintien d'une production spermatique élevée chez les boucs soumis à une $3^{e}$ année de régime photopériodique accéléré. Des rythmes photopériodiques accélérés atténuent, pendant 2 années consécutives, le saisonnement de la reproduction chez le bouc. Afin d'étudier la

${ }^{*}$ Correspondence and reprints 
persistance de l'augmentation de production de semence chez les mâles soumis à ces traitements photopériodiques, les animaux ont été soumis à de tels rythmes pendant une troisième année d'étude. Trois groupes de 6 boucs de races Alpine et Saanen ont été utilisés. Le groupe témoin est maintenu dans les conditions photopériodiques naturelles, tandis que les groupes expérimentaux sont soumis à une altenance d'1 mois de jours longs et d'1 mois de jours courts (lot $2 M$ ), ou de 2 mois de jours longs et 2 mois de jours courts (lot $4 M$ ). Les variations des taux de prolactine indiquent que les boucs des 2 groupes expérimentaux répondent aux changements lumineux, puisque la concentration plasmatique est significativement plus élevée en jours longs (moyenne \pm esm; $2 M$ : $61,1 \pm 15,9 \mathrm{ng} / \mathrm{ml}$ et $4 M: 102,2 \pm 13,5)$ qu'en jours courts $(35,3 \pm 8,2$ et $46,1 \pm 9,0$ respectivement). Les concentrations plasmatiques de testostérone varient également selon la durée du jour $(P<$ 0,0001 ). Dans les 2 groupes expérimentaux la concentration plasmatique est plus élevée en jours longs $(2 \mathrm{M}: 7,0 \pm 0,7 \mathrm{ng} / \mathrm{ml}$ et $4 \mathrm{M}: 10,2 \pm 1,1)$ qu'en jours courts $(4,3 \pm 0,4$ et $5,0 \pm 0,9$ respectivement). Les boucs du groupe témoin manifestent un comportement sexuel intense puisque le pourcentage de boucs refusant d'éjaculer ne dépasse jamais 10\%. Au contraire, dans les lots expérimentaux, le pourcentage de refus est plus élevé: $25,6 \%$ dans le groupe $2 M$ et $28,1 \%$ dans le $4 M(P<0,01)$. Dans le groupe témoin, le poids testiculaire varie avec la saison de 120,0 $\pm 0,09 \mathrm{~g}$ en mai à 155,0 $4,2 \mathrm{~g}$ en novembre. Par contre, dans les lots expérimentaux, cette variation saisonnière n'existe plus et le poids testiculaire est maintenu à une valeur élevée. Dans le groupe $2 \mathrm{M}$, le poids testiculaire est identique entre mai $(160,0 \pm 7,3 \mathrm{~g})$ et novembre $(151,6 \pm 7,3 \mathrm{~g})$; la même observation est faite dans le groupe $4 M(155,0 \pm 11,8$ et $160,0 \pm 12,2 \mathrm{~g}$, respectivement). Le nombre total moyen de spermatozoïdes par éjaculat au cours de l'année est plus élevé $(P<0,05)$ dans les lots $2 M\left(7,8 \pm 0,5 \times 10^{9}\right.$ $\mathrm{spz})$ et $4 \mathrm{M}\left(7,8 \pm 0,3 \times 10^{9} \mathrm{spz}\right)$ que dans le lot témoin $\left(5,0 \pm 0,2 \times 10^{9} \mathrm{spz}\right)$. La production spermati. que par jour, mesurée pendant des collectes intensives à la suite de tests d'épuisement situés à la fin de la période expérimentale, est également plus élevée $(P<0,05)$ dans les lots $2 M\left(3,68 \pm 0,59 \times 10^{9}\right.$ $\mathrm{spz})$ et $4 M\left(6,25 \pm 0,61 \times 10^{9} \mathrm{spz}\right)$ que dans le lot témoin $\left(2,96 \pm 0,36 \times 10^{9} \mathrm{spz}\right)$. Il est conclu que les alternances rapides entre jours longs et jours courts atténuent, pendant la troisième année d'application, le saisonnement de l'activité de l'axe hypothalamus-hypophyse-testicule et permettent le maintien d'une production spermatique élevée.

\section{photopériode / testostérone / prolactine / testicule / bouc}

\section{INTRODUCTION}

Photoperiod is the main environmental cue that controls the reproductive activity of sheep and goats originating in temperate latitudes (Ortavant et al, 1985; Chemineau et al, 1986; Branca and Cappai, 1989) and in males of these species, the breeding season starts in September and ends in February (Corteel, 1977; Lincoln, 1989). In Alpine and Saanen bucks, the breeding season is preceded by a progressive rise in luteinizing hormone (LH) secretion from June to September and a more rapid increase in testosterone secretion from August to September (Rouger, 1974; Delgadillo and Chemineau, 1992). Due to the increase in the secretion of these reproductive hormones, there is an increase in sexual behavior, testis weight and quantitative and qualitative sperm production during the breeding season (Pelletier et al, 1988; Delgadillo et al, 1991, 1992).

It has recently been reported that rapid alternations between long and short days decreased or abolished the seasonal variation in $\mathrm{LH}$ and testosterone secretion and sperm production in lle-de-France rams (Pelletier and Almeida, 1987; Almeida and Pelletier, 1988; Chemineau et al, 1988) and Alpine and Saaneen bucks (Delgadillo et al, 1991; Delgadillo and Chemineau, 1992). In these bucks, 1 or 2 months of long days alternated with 1 or 2 months of short days prevented reproductive seasonality for 2 consecutive years (Delgadillo et al, 1991). To investigate the long-term effect of short photoperiodic cycles on the sexual activity 
of these animals, a third consecutive year of study was carried out on the same bucks experiencing the same photoperiod photoperiodic treatments. The testosterone and testis weight data obtained during this additional experimental year and those obtained from sperm exhaustion tests, performed at the beginning of the fourth year, are presented in this paper.

\section{MATERIALS AND METHODS}

The general materials and methods used in this study have been described previously (Delgadillo et al, 1991; Delgadillo and Chemineau, 1992).

\section{Photoperiodic treatments}

Experimental groups comprised the same Alpine and Saanen bucks which had previously been divided into 3 groups of 6 bucks and maintained for $3 \mathrm{yr}$ in the same photoperiodic treatments. The control group was kept in open sheds under natural day length, which varied from $16 \mathrm{~h}$ light at the summer solstice to $8 \mathrm{~h}$ light at the winter solstice (group C). The second group (2M) was subjected alternately to 1 month of long days (16 h light and $8 \mathrm{~h}$ darkness; $16 \mathrm{~L} /$ $8 \mathrm{D})$ and 1 month of short days $(8 \mathrm{~L} / 16 \mathrm{D})$. The third group (4M) was exposed to alternations of 2 months of long days ( $16 L / 8 D$ ) and 2 months of short days $(8 L / 16 D)$.

\section{Blood sampling and assays}

All blood samples were collected once a week at $14.00 \mathrm{~h}$ throughout the year by jugular venupuncture; the plasma removed after centrifugation at $2500 \mathrm{~g}$ for $20 \mathrm{~min}$ and then stored at $-15^{\circ} \mathrm{C}$ until they were assayed for prolactin and testosterone. Prolactin was determined by a single assay using the method of Kann (1971) and the sensitivity of this assay was $1.7 \mathrm{ng} / \mathrm{ml}$, with an intra-assay coefficient of variation (CV) of $8.9 \%$ at $74 \mathrm{ng} / \mathrm{ml}$. Testosterone was assayed by a single assay using the method of Garnier et al (1978) and the sensitivity of this assay was
$0.2 \mathrm{ng} / \mathrm{ml}$, with intra-assay $\mathrm{CVs}$ of $5.4 \%$ at 5.4 $\mathrm{ng} / \mathrm{ml}$ and $17.4 \%$ at $0.65 \mathrm{ng} / \mathrm{ml}$.

\section{Measurement of reproductive parameters}

Testicular weight was measured once a month by comparative palpation with an orchidometer (Oldham et al, 1978) and sexual behavior assessed twice a week in each semen collection session by recording the percentage of bucks unable to ejaculate into an artificial vagina. The bucks, which had been trained previously to mount a teaser doe, were allowed $3 \mathrm{~min}$ to mount an intact oestrus-induced doe.

The semen of bucks was simultaneously collected and, in each collection session, there was only 1 attempt to obtain 1 ejaculate. The total number of spermatozoa per ejaculate was calculated by measuring the volume and sperm concentration with a spectrophotometer (Spectronic 21; Bausch \& Lomb) of the ejaculate. Two months after the end of the third experimental year, in February, daily sperm output (DSO) was assessed in control and experimental bucks from collections made twice daily for 9 consecutive days following sperm exhaustion tests. Sperm exhaustion tests were composed of 12 attempts of collection per $d$ during the 3 days preceding the 9 days of DSO measurements.

\section{Analysis of data}

In the control group, monthly means of prolactin and testosterone were estimated and analyzed by Analysis of Variance (ANOVA) with repeated measurements (bucks, time). In groups $2 \mathrm{M}$ and $4 \mathrm{M}$, mean concentrations were calculated during 2 consecutive (group 2M) or successive (group 4M) months of long days or short days, and then these mean concentrations were analyzed by ANOVA with repeated measurements (group, prevailing day length and time)

In each group, an individual monthly mean of testicular weight, sexual behavior (defined as the percentage of successful collections over 810 attempts per month) and quantitative sperm production was calculated. Groups then were compared by ANOVA with repeated measure- 
ments (bucks, time) and monthly means of the 3 groups were compared by Duncan's new Multiple Range test.

In the 3 groups the mean daily sperm output was calculated and analyzed by ANOVA with repeated mesures (group, time and interaction) and the daily means compared by Duncan's new Multiple Range test. Results are expressed as mean \pm SEM and all statistical analyses were performed with Superanova software (Abacus Concept).

\section{RESULTS}

\section{Prolactin secretion}

In the control group, there was a significant effect of time $(P<0.0001)$ on the plasma concentration of prolactin. In this group, prolactin release showed marked seasonal variations and high plasma prolactin concentrations occurred in spring and summer, with the highest value in May $(61.9 \pm 14.5 \mathrm{ng} / \mathrm{ml})$. In contrast, lower plasma prolactin concentrations were recorded in autumn and winter, with the lowest value observed in November $(4.9 \pm 0.8 \mathrm{ng} /$ $\mathrm{ml})$. There was a significant effect of day length on prolactin secretion in both experimental groups. The mean plasma levels of prolactin were much higher $(P<0.005)$ during long days $(2 \mathrm{M}: 61.1 \pm 15.9 \mathrm{ng} / \mathrm{ml}$; $4 \mathrm{M}: 102.2 \pm 13.5 \mathrm{ng} / \mathrm{ml}$ ) than during short days (2M: $35.3 \pm 8.2 \mathrm{ng} / \mathrm{ml}$; $4 \mathrm{M}$ : $46.1 \pm$ $9.0 \mathrm{ng} / \mathrm{ml}$ ).

\section{Testosterone secretion}

Testosterone secretion in the control group varied significantly with time $(P<$ 0.0001 ). Testosterone plasma levels remained basal from January to June, rose suddenly from August to September and then decreased progressively until December (fig 1). In light-treated bucks, plasma testosterone concentration was affected by day length $(P<0.0001)$, since secretion was enhanced by short days in both experimental groups. In group $4 \mathrm{M}$, a distinct rise occurred following transfer from long to short days, while in group $2 \mathrm{M}$, the cyclicity was less clear, probably due to more frequent photoperiodic shifts. In both groups, testosterone concentrations were significantly higher $(P<0.05)$ during long days (2M: $7.0 \pm 0.7 \mathrm{ng} / \mathrm{ml} ; 4 \mathrm{M}: 10.2 \pm 1.1 \mathrm{ng} / \mathrm{ml}$ )

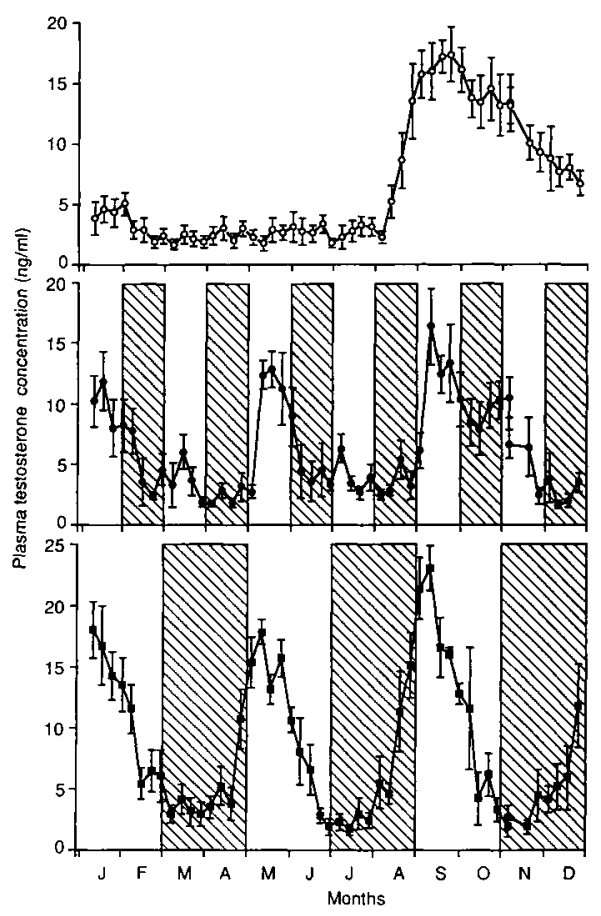

Fig 1. Mean weekly changes ( \pm SEM) in the mean concentration of plasma testosterone of Alpine and Saanen bucks of 3 groups subjected to photoperiodic changes. The grey areas indicate the months when the experimental animals were exposed to short days. Control (O): natural photoperiodic variations at $46^{\circ} \mathrm{N}$ latitude; $2 \mathrm{M}$ (O): alternation between 1 month of long days (16L / $8 \mathrm{D})$ and 1 month of short days ( $8 \mathrm{~L} / 16$ $D) ; 4 \mathrm{M}(\square)$ : alternation between 2 months of long days (16 $L / 8 D$ ) and 2 months of short days ( $8 L / 16 \mathrm{D})$. 
than during short days (2M: $4.3 \pm 0.4 \mathrm{ng} /$ $\mathrm{ml} ; 4 \mathrm{M}: 5.0 \pm 0.9 \mathrm{ng} / \mathrm{ml}$ ).

\section{Sexual behavior}

There was a significant difference in the sexual behavior between the 3 groups $(P<$ $0.001)$. Although the control group was different from group $2 \mathrm{M}(P<0.05)$, there was no significant difference between the controls and group $4 \mathrm{M}$ nor between groups $2 \mathrm{M}$ and $4 \mathrm{M}$. Further, bucks from the control group did not show seasonal variation in their sexual behavior and the percentage that were unable to ejaculate never exceeded $10 \%$ (fig 2 ). In both experimental groups, the percentage of bucks that did not ejaculate varied considerably throughout the year. The highest percentages of bucks from groups $2 \mathrm{M}$ and $4 \mathrm{M}$ that did not ejaculate were observed in December (25.6\%) and August (28.1\%). An ag-gressive behavior towards humans appeared in both experimental groups and this behavior was more marked in group $4 \mathrm{M}$ than in group $2 \mathrm{M}$.

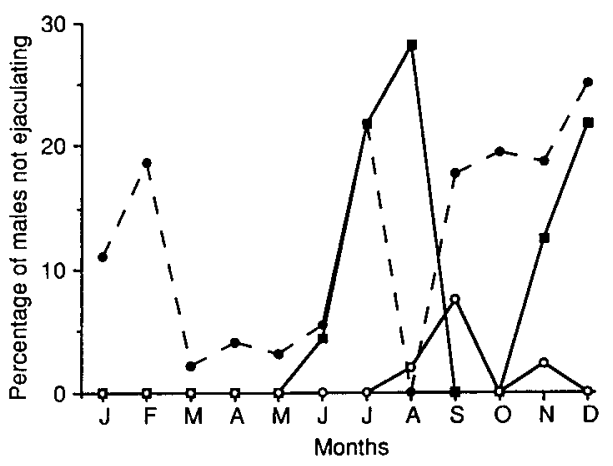

Fig 2. Monthly mean percentage of Alpine and Saanen bucks refusing to ejaculate in the 3 groups, subjected to photoperiodic changes. Control (O): natural photoperiodic variations at $46^{\circ} \mathrm{N}$ latitude; $2 \mathrm{M}(\mathbf{O})$ : alternation between 1 month of long days (16L/8 D) and 1 month of short days $(8 \mathrm{~L} / 16 \mathrm{D})$; $4 \mathrm{M}(\mathrm{D})$ ): alternation between 2 months of long days ( $16 L / 8 D$ ) and 2 months of short days $(8 \mathrm{~L} / 16 \mathrm{D})$.

\section{Testicular weight}

A significant effect of the group $(P<$ $0.0001)$ and time $(P<0.01)$ was detected on testis weight, but the interaction between group and time was not significant. The mean testis weight of the control group was different from experimental groups $(P<0.005)$ but the experimental groups were not different from each other.

Testis weights of controls displayed large seasonal variations, with the lowest values recorded in May $(120.0 \pm 0.0 \mathrm{~g})$ and peak values in November (155.0 $\pm 4.2 \mathrm{~g}$; fig 3). Conversely, these seasonal variations were abolished in experimental animals and testicular weight remained at the levels observed during the breeding season in control bucks. Relative to this, in group $2 \mathrm{M}$, the mean testicular weight was $160.0 \pm 7.3 \mathrm{~g}$ in June and $151.6 \pm 7.3 \mathrm{in}$ November, while the corresponding values in group $4 \mathrm{M}$ were $155.0 \pm 11.8 \mathrm{~g}$ and 160.0 $\pm 12.2 \mathrm{~g}$, respectively.

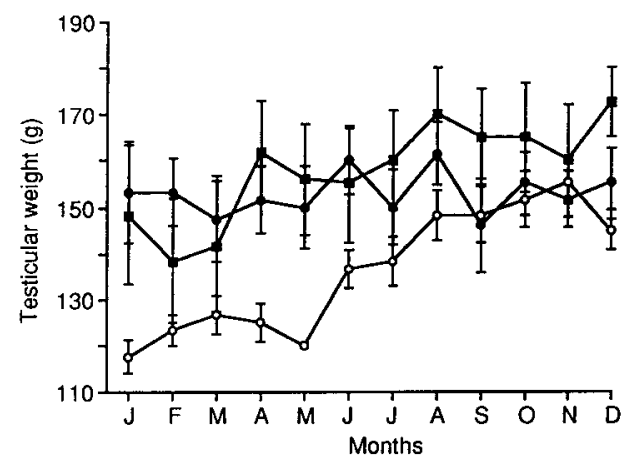

Fig 3. Monthly mean testis weight ( \pm SEM) of Alpine and Saanen bucks of 3 groups, subjected to photoperiodic changes. Control (O): natural photoperiodic variations at $46^{\circ} \mathrm{N}$ latitude; $2 \mathrm{M}$ (O): alternation between 1 month of long days (16L/8 D) and 1 month of short days ( $8 \mathrm{~L} / 16 \mathrm{D})$; 4M ( $\mathrm{B}$ ): alternation between 2 months of long days (16 L/8 D) and 2 months of short days (8 $\mathrm{L}$ $16 \mathrm{D})$. 


\section{Quantitative sperm production during the third year}

A significant effect of the group $(P<0.01)$ was detected on volume of the ejaculate, sperm concentration and total number of spermatozoa per ejaculate. No significant effect of time was detected on these parameters, a significant interaction between group and time was detected only on sperm concentration $(P<0.02)$. The control group was different from both experimental groups for the 3 parameters $(P<0.05)$.

The mean volume of ejaculate from the controls $(1.47 \pm 0.07 \mathrm{ml})$ was lower than that of the experimental animals (2M: 2.15 $\pm 0.12 \mathrm{ml}$; 4M: $1.89 \pm 0.05 \mathrm{ml}$ ).

Important seasonal variations in the mean sperm concentration of ejaculates in the controls were observed. The highest sperm concentration was observed during spring (June: $4.61 \pm 0.35 \times 10^{9}$ spermato$\mathrm{zoa} / \mathrm{ml}$ ). In both experimental groups, seasonal variations in sperm concentration were eliminated since in group $2 \mathrm{M}$, similar values were observed in June (3.40 \pm $0.57)$ and December (3.9 \pm 0.15$)$ and in group $4 \mathrm{M}$, sperm concentration also remained elevated $(4.20 \pm 0.25$ and $4.57 \pm$ 0.38 ). Importantly, the mean total number of spermatozoa per ejaculate in the control group (5.09 $\pm 0.23 \times 109$ spermatozoa) was lower than that of the experimental animals (2M: $7.70 \pm 0.49 ; 4 \mathrm{M}: 7.74 \pm 0.30)$.

\section{Daily sperm output (DSO) during intensive collections after exhaustion tests}

DSO was significantly different between groups $(P<0.05)$. Number of days of semen collection (time) had a significant effect on this parameter $(P<0.0001)$ and a significant interaction between group and time was also found $(P<0.05)$.
Both experimental groups produced more spermatozoa than the control group. Bucks of group $4 \mathrm{M}$ produced significantly more spermatozoa than controls during all the days of semen collection, while DSO of $2 \mathrm{M}$ bucks was higher than that of controls for 7 out of 9 days (fig 4). On the ninth day of semen collection, the mean DSO in the experimental groups $(2 \mathrm{M}: 3.68 \pm 0.59 ; 4 \mathrm{M}$ : $6.25 \pm 0.61)$ was significantly higher than in the controls $(2.96 \pm 0.36 ; P<0.05)$.

\section{Comparison with the second year of production (Delgadillo 1990; Delgadillo et al, 1992)}

Monthly mean ejaculate volumes of control and $4 \mathrm{M}$ bucks were in the same range as those observed during the second year of treatment $(0.8-1.6 \mathrm{ml}$, 2nd yr versus 1.1$1.7,3 \mathrm{rd} \mathrm{yr}$ in control bucks, and $1.8 \mathrm{ml}$ versus 1.9 in $4 \mathrm{M}$ bucks). Mean ejaculate volume of $2 \mathrm{M}$ bucks was higher than that of

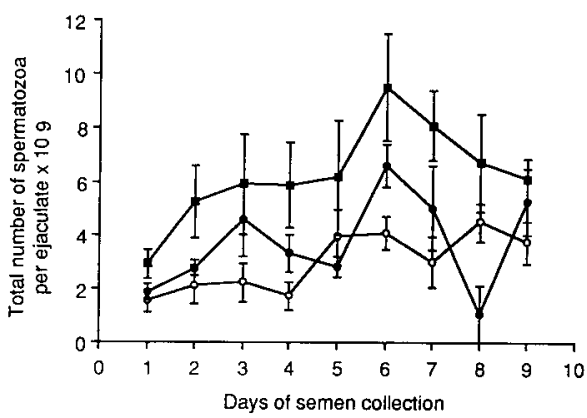

Fig 4. Mean daily sperm output (DSO) ( \pm SEM) during intensive collection (2 daily collections after exhaustion tests) of Alpine and Saanen bucks of 3 groups after exposure during 3 consecutive yr to photoperiodic changes. Control (O): natural photoperiodic variations at $46^{\circ} \mathrm{N}$ latitude; $2 \mathrm{M}(1)$ : alternation between 1 month of long days $(16 \mathrm{~L} / 8 \mathrm{D})$ and 1 month of short days $\left(\begin{array}{lll}8 & \mathrm{~L} / 16 & \mathrm{D}\end{array}\right) ; 4 \mathrm{M}(\boldsymbol{\square})$ : alternation between 2 months of long days (16 L/8 D) and 2 months of short days $(8 \mathrm{~L} / 16 \mathrm{D})$. 
the second year (1.3 versus 2.2). Monthly mean sperm concentrations of ejaculates of control and $4 \mathrm{M}$ bucks were in the same range as those observed during the second year of treatment $\left(3.0-4.3 \times 10^{9}\right.$ spermatozoa/ml, 2nd yr versus 2.8-4.6, 3rd yr in control bucks and $3.6-4.7 \times 10^{9}$ spermatozoa $/ \mathrm{ml}$, 2nd yr versus 4.2-4.3, 3rd yr in $4 \mathrm{M}$ bucks). Monthly mean sperm concentrations of ejaculates of $2 \mathrm{M}$ bucks were generally lower than that of the second year $\left(3.7-5.3 \times 10^{9}\right.$ spermatozoa/ml, 2nd yr versus $3.4-3.9,3 \mathrm{rd} \mathrm{yr}$ ).

\section{DISCUSSION}

In the experimental groups, seasonal variations in the prolactin release varied according to the photoperiodic shifts, with long days stimulating and short days inhibiting prolactin secretion. These results and those reported for the first $2 \mathrm{yr}$ of this study by Delgadillo and Chemineau (1992) are very similar and, thus, suggest that bucks are able to interpret adequately rapid changes in day length, which is in agreement with previous studies on bucks and rams (Buttle, 1974; Pelletier et al, 1985; Langford et al, 1987).

In treated bucks, testosterone secretion was also linked, as in the 2 preceding $y r$, to rapid changes in day length, since in these groups, short days significantly stimulated testosterone secretion. As mentioned previously (Delgadillo and Chemineau, 1992), variations in testosterone secretion suggest that steroidogenesis in the testes is able to follow rapid changes in photoperiod. Short photoperiodic cycles dramatically decreased the seasonality of testis weight and sperm production, although the percentage of bucks unable to ejaculate increased in both experimental groups. In group $2 \mathrm{M}$ increase in the percentage of bucks unable to ejaculate was registered throughout the year confirming the observations during the first $2 \mathrm{yr}$ of the experiment (Delgadillo et al, 1991). However, in $4 \mathrm{M}$ bucks, the sexual behavior was different from the previous $2 \mathrm{yr}$ of experiment, since during the last 6 months of the study, a decrease in the sexual behavior appeared and the percentage of bucks that did not ejaculate exceeded $20 \%$. In both experimental groups, the percentage of bucks unable to ejaculate, in some months, reached values identical to those reported for bucks during the rest season (Rouger, 1974; Corteel, 1977). In controls, the percentage of bucks exhibiting decreased sexual behavior during this third experimental year, was lower than that recorded in the same animals during the first $2 \mathrm{yr}$ of this study (Delgadillo et al, 1991) and previous studies (Rouger, 1974; Corteel, 1977) but agrees with results from Cashmere bucks (Restall et al, 1991).

Testosterone secretion, the main hormone responsible for sexual behavior, responded to the prevailing photoperiod, indicating that the inhibited sexual activity of the experimental animals probably had a post-gonadal origin. It is possible that in some $2 \mathrm{M}$ bucks, plasma testosterone levels were able to maintain high spermatogenesis, but that these levels were insufficient to properly stimulate sexual behavior. Indeed, individual variations in the response of the sexual behavior to the same levels of testosterone were reported in rams by D'Occhio and Brooks (1982). However, if this were the reason, then it would be difficult to explain the decreased sexual behavior observed in group $4 \mathrm{M}$ at the end of the study, in which the plasma levels of testosterone were much higher than those of $2 \mathrm{M}$ bucks.

The aggressive behavior, particularly that registered in group $4 \mathrm{M}$, may result from the unusual sustained presence of testosterone during the year in the 2 lighttreated groups of bucks, compared with 
the control group. In controls testosterone concentration was lower than $5 \mathrm{ng} / \mathrm{ml}$ of plasma for 29 weeks (59\%), while the corresponding values for groups $2 \mathrm{M}$ and $4 \mathrm{M}$ were $26(53 \%)$ and 20 weeks $(40 \%)$, respectively. For the 2 light-treated groups, unlike the control group, these weeks were not consecutive.

As a consequence of the seasonal decrease in testis weight of controls, the bucks of the light-treated groups produced a larger number of spermatozoa per ejaculate than controls $(50 \%$ more spermatozoa). This superiority also appeared in the same range during the 2 previous experimental years $(+50$ and $+70 \%$, respectively; Delgadillo et al, 1991) and is in accordance with results reported for lle-deFrance rams (Chemineau et al, 1988). Moreover, the DSO during intensive collection after exhaustion tests, clearly confirmed that bucks from both experimental groups produced more spermatozoa than controls, and that the superior sperm production of the light-treated bucks probably originates from higher efficiency in the spermatogenic processes which differentiate spermatogonia into spermatozoa. This finding suggests that a more frequent collection intensity (5-10 ejaculate per week, instead of 2) from experimental groups during the 3 years of the experiment preceding the measurement of DSO, would probably have led to an increase in the total number of deep-frozen spermcells stored throughout the year. As reported in lle-de-France rams (De Reviers et al, 1992), the superiority of the experimental bucks could be due to the fact that photoperiodic treatments enhanced the differentiation of $A 0$ into $A 1$ spermatogonia maintaining a high spermatogenetic activity throughout the year. From a practical point of view, the use of the $4 \mathrm{M}$ treatment in artificial insemination centers seems preferable as it allows a higher DSO than the $2 \mathrm{M}$ treatment.
In conclusion, these results and those by Delgadillo et al (1991) and Delgadillo and Chemineau (1992), show that rapid alternation of long and short days prevents seasonality of testosterone secretion and testis weight and increases sperm production during 3 consecutive yr, although sexual behavior is slightly, but significantly, decreased.

\section{ACKNOWLEDGMENTS}

We wish to thank J Pelletier and J Thimonier for help with the experimental design of the study; A Daveau, F Maurice, JL Bonné, D Bernelas and $Y$ Berson for technical assistance; A Boisseau and $J$ Boutin for the care of the animals; $B$ Malpaux for discussion of the results and assisting with preparation of the manuscript; and $A$ Bouroche and DC Skinner for help with the English version of the manuscript.

\section{REFERENCES}

Almeida G, Pelletier J (1988) Abolition of the seasonal testis changes in the lle-de-France ram by short light cycles: relationship to luteinizing hormone and testosterone release. Theriogenology 29, 681-691

Branca A, Cappai P (1989) Osservazionni sul controllo della riproduzione nelle specie caprina: esperienze effetuate in Sardegna. Symp Int La riproduzione nei piccolli ruminanti: basi fisiologiche e aspetti applicativi pp 115-129

Butte HL (1974) Seasonal variations of prolactin in plasma of male goats. $J$ Reprod Fertil 37, 95-99

Chemineau $P$, Normant E, Ravault JP, Thimonier $J(1986)$ Induction and persistence of pituitary and ovarian activity in the out-ofseason lactating dairy goat after a treatment combining a skeleton photoperiod, melatonin and the male effect. $J$ Reprod Fertil 78, 497504

Chemineau $P$, Pelletier J, Guerin $Y$, Colas G, Ravault JP, Toure G, Almeida G, Thimonier J, Ortavant R (1988) Photoperiodic and melatonin treatments for the control of seasonal 
reproduction in sheep and goats. Reprod Nutr Dev 28, 409-422

Corteel JM (1977) Production, storage and insemination of goat semen. $\mathrm{In}$ : Management of Reproduction in Sheep and Goats Symposium, University of Wisconsin, Madison, July 24-25 p 41-57

Delgadillo JA (1990) Abolition des variations saisonnières de l'activité sexuelle chez le bouc pour des traitements photopériodiques. Thèse de Doctorat, Univ Sci Tech Languedoc, France, $119 \mathrm{p}$

Delgadillo JA, Chemineau $P$ (1992) Abolition of the seasonal release of luteinizing hormone and testosterone in Alpine male goeats ( $\mathrm{Ca}$ pra hircus) by short photoperiod cycles. $J$ Reprod Fertil 94, 45-55

Delgadillo JA, Leboeuf $B$, Chemineau $P$ (1991) Decrease in the seasonality of sexual behavior and sperm production in bucks by exposure to short photoperiodic cycles. Theriogenology $36,755-770$

Delgadillo JA, Leboeuf B, Chemineau P (1992) Abolition of seasonal variations in semen quality and maintenance of sperm fertilizing ability by photoperiodic cycles in goats bucks. Small Ruminant Res 9, 47-59

D'Occhio MJ, Brooks DE (1982) Threshold of plasma testosterone required for normal mating activity in male sheep. Horm Behav 16, 383-394

De Reviers MT, Perreau C, Pisselet C, Pelletier $J$ (1992) Effect of a 2 month light cycle regimen on testicular parameters of adult lle-deFrance rams. Microscopy Research and Technique 20, 268-273

Garnier DH, Cotta Y, Terqui M (1978) Androgen immunoassay in the ram: results of direct plasma testosterone and the dehydrosepiandrosterone measurement and physiological evaluation. Ann Biol Anim Biochim Biophys $18,265-281$
Kann G (1971) Dosage radio-immunologique de la prolactine plasmatique chez les ovins. $C R$ Acad Sc Paris Série D 272, 2808-2811

Landford GA, Ainsworth L, Marcus GJ, Sherstha JNB (1987) Photoperiod entrainment of testosterone, luteinizing hormone, folliclestimulating hormone, and prolactin cycles in ram in relation to testis size and semen quality. Biol Reprod 37, 489-499

Lincoln GA (1989) Seasonal aspects of testicular function. In: The Testis $(\mathrm{H}$ Burger and $\mathrm{D}$ de Krester eds) Raven Press, NY, 329-385

Oldham CM, Adams NR, Gherardi PB, Lindsay DR, Mckintosh JB (1978) The influence of level of feed intake on sperm-producing capacity of testicular tissue in the ram. Aust $J$ Agric Res 29, 173-179

Ortavant R, Pelletier J, Ravault JP, Thimonier J, Volland-Nail $P$ (1985) Photoperiod: main proximal and distal factor of the circannual cycle of reproduction in farm animals. In: $O x$ ford Reviews of Reproductive Biology, Oxford Univ Press 7, 305-345

Pelletier J, Brieu V, Ravault JP (1985) Entrainement et stimulation par la lumière de la sécrétion de la prolactine chez le bélier. $C R$ Acad Sc Paris Série III 301, 323-328

Pelletier J, Chemineau P, Delgadillo JA (1988) Seasonality of sexual activity and its photoperiodic control in the adult ram and he-goat. In: Proc 11 th Intern Congr Anim Reprod \& Artif Insem, Dublin 25-30 June 5, 211-219

Restall BJ, Walkden-Brown S, Henniawati Restall (1991) Reproduction research in Australian goats. In: Cashmere Research Seminar Proceedings, 23-24 May (NSW Agriculture \& Fisheries eds) 49-69

Rouger Y (1974) Étude des interactions de l'environnement et des hormones sexuelles dans la régulation du comportement des Bovidae. Thèse Doctorat ès Sciences Naturelles, University of Rennes, France $197 \mathrm{p}$ 